\title{
Community Characteristics in COVID-19 Preventive Precautions
}

\author{
Sri Ratna Rahayu ${ }^{1}$, Intan Zainafree ${ }^{2}$, Aufiena Nur Ayu Merzistya ${ }^{3}$, \\ Tika Dwi Cahyani ${ }^{4}$ \\ \{ sriratnarahayu@mail.unnes.ac.id ${ }^{1}$, intan_zainafree@yahoo.com ${ }^{2}$, finamerzistya@gmail.com ${ }^{3}$ \} \\ Universitas Negeri Semarang, Semarang, Indonesia ${ }^{123}$
}

\begin{abstract}
The number of COVID-19 cases in Indonesia until April 25 $5^{\text {th }}, 2020$ was 8.211 cases and already tends to increase every day. To reduce the increase in cases, it's important to make efforts to prevent transmission of COVID-19. This study aimed to analyze the relationship between community characteristics with COVID-19 prevention. The study design used cross-sectional with 350 samples that were $\geq 15$ years old and domicile in Semarang. Samples were selected by random sampling technique. Data was collected through an online questionnaire and analyzed using the Logistic Regression Test. The result of this research is known that there was a relationship between age, education, and occupation toward social distancing $(\mathrm{p}<0.05)$; sex, age, and education level toward mask-wearing $(\mathrm{p}<0.05)$; age, education level, and occupation toward using hand sanitizer using $(\mathrm{p}<0.05)$ statistically. It can be concluded that community characteristics are related to COVID-19 preventive precautions.
\end{abstract}

Keywords: COVID-19, characteristic, prevention.

\section{Introduction}

World Health Organization (WHO) since January $30^{\text {th }}, 2020$, established Coronavirus diseases (COVID-19) as a Public Health Emergency of International Concern (PHEIC) [1]. This is because COVID-19 is a public health event that is dangerous and raises health risks to other countries through the spread of disease internationally [2]. More than 2,804,796 confirmed COVID-19 cases and 182,100 deaths by April $26^{\text {th }}, 2020$, in the world [3].

COVID-19 has spread to 186 countries, including Indonesia [4]. A total of 8,211 positive cases were recorded with 1,002 cures and 689 deaths by April 25 ${ }^{\text {th }}, 2020$, and these cases are predicted to continue increasing every day [5]. Since January $28^{\text {th }}$, 2020, the relevant Ministries together with the National Disaster Management Agency (BNPB) set Indonesia in a state of emergency for the COVID-19 epidemic [6], so that efforts were made to immediately handle and prevent COVID-19 transmission so that the spread of the virus would not be more widespread. WHO has provided general guidelines for the prevention and treatment of COVID-19 that can be carried out by 
affected countries [7]. Besides, WHO also encourages the public to take preventative precautions to reduce the spread of COVID-19 which is increasingly widespread [8].

Recommendations from WHO are also carried out by Indonesia, where Indonesia has begun to establish regulations and appeals to the public to take steps to prevent COVID-19. These efforts include working from home rules, learning from home, restrictions on community activities, the obligation to wear a mask when leaving the house, washing hands with soap, social distancing, the prohibition of gathering, restrictions on worship in places of worship, health protocols in public places, provision of facilities health for COVID-19, a rapid examination of COVID-19 in some areas, and so on [9].

Prevention efforts are carried out in all parts of Indonesia, one of them is Semarang City. The city of Semarang is the region with the highest COVID-19 case in Central Java [10]. A total of 129 positive cases with 75 deaths and 30 cures [11]. Starting April 27, 2020, the Semarang City established the implementation of Community Activity Restrictions (in Bahasa, Pembatasan Kegiatan Masyarakat: PKM). The intended PKM is in the form of restrictions on outdoor activities by everyone who lives in the Semarang City area [12].

No vaccine to date requires COVID-19 treatment efforts, one of which is through non-pharmaceutical interventions and several mitigation strategies, one of which is community-based [13]. Effective community-based prevention and control play an important role in controlling COVID-19 in China [14]. This is because the community (human) is the host of COVID-19, in which the COVID-19 virus is transmitted between humans through direct or indirect contact with infected patients [15]. The host is one important component in the degree of public health so that the control and prevention of disease are closely related to the characteristics [16] and behavior of the community itself [17]. Host factors can include age, gender, lifestyle, genetic predisposition, education, professional status, personality. Determinants of individual position in the social hierarchy are the level of education, profession, and income [18]. Therefore we must know the characteristics of the community to develop prevention programs to be more effective.

So from this explanation, it is necessary to develop research that examines the characteristics of the community in the prevention of COVID-19 as an effort to deal with COVID-19. This study aims to analyze the relationship of community characteristics to COVID-19 preventive precautions

\section{Method}

This study used a cross-sectional study. The independent variables were the characteristics of the community including age, sex, education, and occupation, while the dependent variables were COVID-19 preventive precautions in the form of mask wear, hand washing, hand sanitizer use, and social distancing. A total of 350 Semarang citizens were selected to be sampled in this study with random sampling techniques with criteria: people aged $\geq 15$ years old and domiciled in the Semarang City during the COVID-19 pandemic (since March 2020 until Juni 2020). The existence of the COVID-19 pandemic required researchers to continue to do government advice by reducing contact with others, so that data collection is done 
through an online questionnaire filled out by respondents online. Then, Data were analyzed by Logistic test on variables with categorical data scales and Mann Whitney Test on numerical data scale variables.

\section{Result}

A total of 350 people with predetermined criteria are willing to become respondents of this study by filling out an online questionnaire. Based on table 1 it can be seen that from 350 respondents, $30.9 \%$ were male. Most of the respondents $(51.1 \%)$ were diploma/bachelor graduates and only $0.3 \%$ were not in school or graduated from elementary school. Meanwhile, $34.6 \%$ of respondents did not work, the highest number being in the occupational group. The average age of respondents who took the study was 34.41 years, with a minimum age of 15 years and a maximum age of 69 years. Standard intersection (SD) in the age group is worth 14.17.

Table 1. Frequency distribution of COVID-19 preventive precautions $(\mathrm{n}=350)$

\begin{tabular}{lll}
\hline Characteristic & Frequency & Percentage (\%) \\
\hline Sex & & \\
Men & 108 & 30.9 \\
$\quad$ Woman & 242 & 69.1 \\
Education level & & \\
$\quad$ Not school or Elementary school & 1 & 0.3 \\
High School & 115 & 32.9 \\
Diploma/Bachelor & 179 & 51.1 \\
Master or Doctoral & 55 & 15.7 \\
Occupation & & \\
Entrepreneurs & 41 & 11.7 \\
Daily labors & 8 & 1.3 \\
Employees & 94 & 26.9 \\
Government Employees & 85 & 24.3 \\
Farmers/Fishermen & 1 & 0.3 \\
Not work & 121 & 34.6 \\
\hline Characteristic & Mean & Standard \\
\hline Age (15 -69 years old) & 34.41 & 14.17 \\
\hline
\end{tabular}

Table 2 shows the proportion of sex, education level, and type of community work in COVID-19 preventive precautions. Prevention of COVID-19 in this study is categorized into 4 categories, namely (1) social distancing actions, (2) actions of wearing masks when traveling out, (3) actions of washing hands, and (4) actions of using hand sanitizers. The results of this study can be seen in the following table. 
Table 2. The proportion of characteristic toward COVID-19 preventive precautions $(n=350)$

\begin{tabular}{|c|c|c|c|c|c|c|c|c|}
\hline \multirow{3}{*}{ Characteristics } & \multicolumn{8}{|c|}{ Preventive Precautions } \\
\hline & \multicolumn{2}{|c|}{$\begin{array}{l}\text { Social } \\
\text { distancing }\end{array}$} & \multicolumn{2}{|c|}{ Mask wearing } & \multicolumn{2}{|c|}{ Hand washing } & \multirow{2}{*}{$\begin{array}{l}\text { Hand } \\
\text { using }\end{array}$} & \multirow{2}{*}{$\begin{array}{l}\text { sanitizer } \\
\text { Yes } \\
\end{array}$} \\
\hline & No & Yes & No & Yes & No & Yes & & \\
\hline \multicolumn{9}{|l|}{ Sex } \\
\hline $\operatorname{Men}(\%)$ & $\begin{array}{l}48 \\
(34.5)\end{array}$ & $\begin{array}{l}60 \\
(28.4)\end{array}$ & $\begin{array}{l}6 \\
(66.7)\end{array}$ & $\begin{array}{l}102 \\
(29.9)\end{array}$ & $\begin{array}{l}2 \\
(28.6)\end{array}$ & $\begin{array}{l}106 \\
(30.9)\end{array}$ & $\begin{array}{l}27 \\
(32.1)\end{array}$ & $\begin{array}{l}81 \\
(30.5)\end{array}$ \\
\hline Woman $(\%)$ & $\begin{array}{l}91 \\
(65.5)\end{array}$ & $\begin{array}{l}151 \\
(71.6)\end{array}$ & $\begin{array}{l}3 \\
(33.3)\end{array}$ & $\begin{array}{l}239 \\
(70.1)\end{array}$ & $\begin{array}{l}5 \\
(71.4)\end{array}$ & $\begin{array}{l}237 \\
(69.1)\end{array}$ & $\begin{array}{l}57 \\
(67.9)\end{array}$ & $\begin{array}{l}185 \\
(69.5)\end{array}$ \\
\hline \multicolumn{9}{|l|}{ Education level } \\
\hline $\begin{array}{l}\text { Elementary/High School } \\
(\%)\end{array}$ & $\begin{array}{l}20 \\
(14.4)\end{array}$ & $\begin{array}{l}96 \\
(45.5)\end{array}$ & $\begin{array}{l}7 \\
(77.8)\end{array}$ & $\begin{array}{l}109 \\
(32.0)\end{array}$ & $\begin{array}{l}3 \\
(42.9)\end{array}$ & $\begin{array}{l}113 \\
(32.9)\end{array}$ & $\begin{array}{l}38 \\
(45.2)\end{array}$ & $\begin{array}{l}78 \\
(29.3)\end{array}$ \\
\hline $\begin{array}{l}\text { Diploma/Bachelor/Master } \\
\text { /Doctoral }(\%)\end{array}$ & $\begin{array}{l}119 \\
(85.6)\end{array}$ & $\begin{array}{l}115 \\
(54.5)\end{array}$ & $\begin{array}{l}2 \\
(22.2)\end{array}$ & $\begin{array}{l}232 \\
(68.0)\end{array}$ & $\begin{array}{l}4 \\
(57.1)\end{array}$ & $\begin{array}{l}230 \\
(67.1)\end{array}$ & $\begin{array}{l}46 \\
(54.8)\end{array}$ & $\begin{array}{l}188 \\
(70.7)\end{array}$ \\
\hline \multicolumn{9}{|l|}{ Occupation } \\
\hline Work $(\%)$ & $\begin{array}{l}104 \\
(74.8)\end{array}$ & $\begin{array}{l}84 \\
(39.8)\end{array}$ & $\begin{array}{l}3 \\
(33.3)\end{array}$ & $\begin{array}{l}185 \\
(54.3)\end{array}$ & $\begin{array}{l}4 \\
(57.1)\end{array}$ & $\begin{array}{l}184 \\
(53.6)\end{array}$ & $\begin{array}{l}35 \\
(41.7)\end{array}$ & $\begin{array}{l}153 \\
(57.5)\end{array}$ \\
\hline Not work $(\%)$ & $\begin{array}{l}35 \\
(25.2)\end{array}$ & $\begin{array}{l}127 \\
(60.2)\end{array}$ & $\begin{array}{l}6 \\
(66.7)\end{array}$ & $\begin{array}{l}156 \\
(45.7)\end{array}$ & $\begin{array}{l}3 \\
(42.9)\end{array}$ & $\begin{array}{l}159 \\
(46.4)\end{array}$ & $\begin{array}{l}49 \\
(58.3)\end{array}$ & $\begin{array}{l}113 \\
(42.5)\end{array}$ \\
\hline
\end{tabular}

As seen in the table above, in overall and quantity, there were more respondents in the COVID-19 preventive group than in the response group who did not prevent COVID-19. The proportion of men who did not do social distancing (34.5\%) was greater than with the proportion of men who did social distancing $(28.4 \%)$. In the education level group, respondents with Diploma/Bachelor/Master/ Doctoral education level who did not do social distancing had a greater proportion (85.6\%) compared to they did social distancing (54.5\%). Meanwhile, in the working group, the proportion of working people who did not social distancing (74.8\%) was greater than the proportion of working people who did social distancing (39.8\%).

Then, for the proportion of men who did not wear masks when leaving the house $(66.7 \%)$ more than the proportion of men who wore masks when leaving the house (29.9\%). In the education level group, it is seen in a quantity that most have worn masks when leaving the house. Even so, the proportion of people with Elementary/High School education level who did not wear masks (77.8\%) is greater than that of people with Elementary/High School education level who wore masks $(32 \%)$. Whereas in the workgroup, the proportion of working people who wore masks when doing activities outside the home $(54.3 \%)$ is greater than not wearing masks when doing activities outside (33.3\%).

In COVID-19 preventive precautions by washing hands, the number of respondents in the education level group did hand washing more than the number of groups who did not wash their hands. Similarly, the proportion, men who washed their hands (30.9\%) were greater than men who did not wash their hands (28.6\%). The proportion of Elementary/High School graduates who did not wash their hands (42.9\%) was 
greater than the proportion of Elementary/High School graduates who washed their hands $(32.9 \%)$. As with the workgroup, the proportion of working people who did not wash their hands $(57.1 \%)$ was greater than the proportion of working people who washed their hands $(53.6 \%)$.

The proportion of men who did not use hand sanitizer $(32.1 \%)$ was greater than the proportion of men who used hand sanitizer (30.5\%). Meanwhile, in the education level group, the proportion of diploma/bachelor/master/doctoral graduates who used hand sanitizers $(70.7 \%)$ was greater than the proportion of diplo$\mathrm{ma} /$ bachelor/master/doctoral graduates who did not use hand sanitizers (54.8\%). The proportion of working people who used hand sanitizers $(57.5 \%)$ is greater than the proportion of working people who did not use hand sanitizers $(41.7 \%)$.

Table 3. The relationship between community characteristics with social distancing

\begin{tabular}{llll}
\hline Characteristics & Significance & $\begin{array}{l}\text { Prevalence } \\
\text { Ratio (PR) }\end{array}$ & $\begin{array}{l}\text { Confidence } \\
\text { Interval } \\
\mathbf{9 5 \%} \text { CI) }\end{array}$ \\
\hline Sex & 0.150 & 0.68 & $0.41-1.15$ \\
Age (years) & $<0.01^{*}$ & & \\
Education level & $<0.01^{*}$ & 0.20 & $0.12-0.35$ \\
Occupation & $<0.01^{*}$ & 4.49 & $2.80-7.20$ \\
\hline
\end{tabular}

*significant $(\mathrm{p}<-0.05)$

Based on the relationship table above it is known that the significance value (pvalue) in the age, education level, and occupation group were less than 0.05 $(p=<0.01)$. Then there was a relationship between age, education level, and occupation on COVID-19 preventive precautions by conducting social distancing. The prevalence ratio (PR) value of education level was 0.20 , which means that the education level as a protective factor of social distancing behavior $(\mathrm{PR}<1)$. So, diplo$\mathrm{ma} /$ bachelor/master/doctoral graduates had the risk of not doing social distancing 0.2 times than elementary/high school graduates. Meanwhile, the PR value of occupation was 4.49 , which means people who had a job were 4.49 times more at risk of not doing social distancing than people who had no job.

Table 4. The relationship between community characteristics with mask-wearing

\begin{tabular}{llll}
\hline Characteristics & Significance & $\begin{array}{l}\text { Prevalence } \\
\text { Ratio }(\mathbf{P R})\end{array}$ & $\begin{array}{l}\text { Confidence } \\
\text { Interval } \\
\mathbf{( 9 5 \%} \text { CI) }\end{array}$ \\
\hline Sex & $0.036^{*}$ & 0.21 & $0.05-0.91$ \\
Age (years) & $0.006^{*}$ & & \\
Education level & $0.004^{*}$ & 7.45 & $1.52-36.45$ \\
Occupation & 0.214 & 0.42 & $0.10-1.71$
\end{tabular}

\footnotetext{
*significant $(\mathrm{p}<-0.05)$
} 
The result of the analysis of mask-wearing is shown in table 2. There was a relationship between sex and mask-wearing in the community when leaving the house. Evidenced by the $\mathrm{p}$-value $<0.05(\mathrm{p}=0.036)$. Because of the PR value of sex was less than 1 , so sex as a protective factor of the mask-wearing. This means that women had the risk of not wearing a mask when going out 0.2 times compared to men. Besides, there was also a relationship between age and the behavior of wearing masks when leaving the house $(\mathrm{p}=0.006)$.

For education level, there was a relationship between education level and maskwearing in the community when leaving the house, with the $p$-value was 0.004 . The PR value of education level was 7.45 , so elementary/high school graduates had a 7.45 times greater risk of not wearing a mask when going out than diplo$\mathrm{ma} /$ bachelor/master/doctoral graduates. Unlike occupation, there was no relationship between occupation and mask-wearing in the community because the p-value was 0.214 .

Table 5. Table 5. The relationship between community characteristics with hand washing

\begin{tabular}{llll}
\hline Characteristics & Significance & $\begin{array}{l}\text { Prevalence } \\
\text { Ratio (PR) }\end{array}$ & $\begin{array}{l}\text { Confidence } \\
\text { Interval } \\
(\mathbf{9 5 \%} \text { CI) }\end{array}$ \\
\hline Sex & 0.855 & 1.17 & $0.23-6.25$ \\
Age (years) & 0.464 & & \\
Education level & 0.581 & 1.53 & $0.34-6.94$ \\
Occupation & 0.854 & 1.15 & $0.25-5.23$ \\
$\quad *$ significant $(\mathrm{p}<-0.05)$ & & &
\end{tabular}

In the type of prevention COVID-19, namely washing hands, can be seen in table 6. There was no relationship between community characteristics (sex, age, education level, and occupation) and handwashing behavior. The significance values of all variables were more than 0.05 .

Table 6. The relationship between community characteristics with hand sanitizer using

\begin{tabular}{llll}
\hline Characteristics & Significance & $\begin{array}{l}\text { Prevalence } \\
\text { Ratio (PR) }\end{array}$ & $\begin{array}{l}\text { Confidence } \\
\text { Interval } \\
\mathbf{( 9 5 \% ~ C I ) ~}\end{array}$ \\
\hline Sex & 0.679 & 1.12 & $0.65-1.96$ \\
Age (years) & $<0.01^{*}$ & & \\
Education level & $0.007^{*}$ & 0.50 & $0.30-0.83$ \\
Occupation & $0.011^{*}$ & 0.53 & $0.32-0.87$ \\
\hline
\end{tabular}

*significant $(\mathrm{p}<-0.05)$

Based on table 6, group of age, education level, and occupation had a relationship with hand sanitizer using in community, each p-value in sequence, i.e., <0.01, 0.007, and $0.011(<0.05)$. So The PR value in education level was 0.50 , so education level as a protective factor of hand sanitizer using. Same as occupation, the PR value was 
0.53. It means that as a protective factor. It can be concluded that diplo$\mathrm{ma} /$ bachelor/master/doctoral graduates had the risk of not using hand sanitizer 0.50 times compared to elementary/high school graduates and people who did not work had a risk of not using hand sanitizer 0.53 times than working people.

\section{Discussion}

The World Health Organization (WHO) has advised the public to take precautions to prevent transmission of COVID-19. These precautions include washing hands with running water and soap or alcohol-based hand rub, keeping a minimum distance of 1 meter, avoiding crowds, not touching the face area, closing the mouth when coughing/sneezing, staying at home and wearing a mask when leaving the house, and immediately go to the doctor if you experience symptoms of COVID-19 [8]. This action is important for all levels of society to minimize the risk of transmission and spread of the virus to a wider area [19].

Information about COVID-19 prevention can easily be accessed through all media to increase public awareness about COVID-19 [20], [21]. However, information that can further change people's awareness and behavior can be influenced by several factors, one of which is age [22]. The results of this study show that age is associated with COVID-19 preventive precautions namely social distancing (table 3), wearing a mask when leaving the house (table 4), and using a hand sanitizer instead of water and soap (table 6) statistically, with a statistic the average age of the respondent is 34.41. This can be interpreted as age as an individual factor to do COVID-19 precautions. There is an explanation that supports the results of this study. A person's age will affect the knowledge they receive. In general, the more you age the individual development will increase according to your knowledge and also from the experience you have gained [18]. In addition to knowledge, abilities, and ways of thinking of individuals will also increase [23]. The maturity of individual thinking will affect the actions of these individuals towards events in their environment [24].

Based on the analysis, gender also has a relationship with wearing masks when leaving the house. The behavior of wearing a mask when leaving the house is more done by women than men. Then it can be said that women are more obedient in taking COVID-19 precautions than men. According to WHO, in making risky decisions, men have more courageous behavior than women, including in matters relating to health [25].

Meanwhile, there was also a relationship at the level of education to COVID-19 preventive precautions including, social distancing, mask-wearing, and hand sanitizer using. The higher the individual's education, it will be related to the knowledge gained will be more extensive. This is because more and more information is received so that individuals have more knowledge than the lower level of education [26]. Education will also give a return on individual income, which income will provide convenience in getting wider health information and better health access [27].

There was a statistically significant relationship between occupation and COVID19 preventive precautions, namely social distancing (table 3 ) and hand sanitizer using 
in the community (Table 6). Social distancing is one of action to keep a distance from others to avoid direct contact such as staying at home and reducing outside activities [28]. However, in reality, some respondents did not do social distancing for various reasons. Most respondents leave the house to work and buy daily necessities in supermarkets, markets, and places to buy other household needs. Based on the result of collecting the data, occupations that were held among the 350 respondents in the study included employees, entrepreneurs, civil servants, fishermen, and day laborers. Some of them said that they were forced to leave home because of demands for work that could not be done at home.

In line with research conducted in the United States, it was explained that low socioeconomic status is associated with a lack of social distancing, where the socioeconomic community is associated with income. Life needs that must be met force them to keep working and doing activities outside the home to earn income for survival [29]. This is also supported by the statement of the Ministry of Health of the Republic of Indonesia where the agency or work that provides services and community needs are not required to do work from home but still adhere to the health protocol [30]. So this is evidence that the type of work can be one of the community factors to take COVID-19 preventive precautions, namely social distancing.

There was no relationship between community characteristics and hand washing. This was because almost all respondents claimed to always wash their hands with soap and running water (table 2). They said that washing hands with soap and running water is always before, during, and after the activity. This makes it possible that there is no relationship between the characteristics of the community with handwashing behavior because most people based on age, occupation, and education have understood the importance of washing hands with soap and running water

\section{Conclusion}

The results of this study indicate that most people in Semarang City have taken COVID-19 preventive precautions including social distancing, wearing masks when leaving the house, washing their hands, and using hand sanitizers instead of water and soap. It can be seen that there is a relationship between age, sex, level of education, and type of work against COVID-19 preventive precautions. In more detail, there is a relationship between sex and age on behavior in wearing masks; age, master / doctoral education level, and type of work of farmers/fishermen on social distancing; and the age and type of occupation of farmers/fishermen on behavior in using hand sanitizers statistically. So there should be a COVID-19 control and prevention program by taking into account the characteristics of the people in each region. This is because in each region there are differences in the characteristics of the community so that the program is far more effective. 


\section{Acknowledgments}

Although amid the COVID-19 pandemic that occurred in Indonesia today, which forced researchers to continue carrying out research but by complying with government regulations. So, we extend our thanks to those who have helped the research run. Thank you to the Faculty of Sports Science, Universitas Negeri Semarang for granting permission and funding for this research, so that it can run smoothly according to researchers' expectations. To our respondents, we also thank you for being willing to become respondents of our research and filling out the questionnaire that we gave online through social media.

\section{References}

[1] WHO, "Statement on the second meeting of the International Health Regulations (2005) Emergency Committee regarding the outbreak of novel coronavirus (2019-nCoV)," World Health Organization, 2020.

[2] WHO, "IHR Procedures concerning public health emergencies of international concern (PHEIC)," Strengthening health security by implementing the International Health Regulations (2005), 2020.

[3] WHO, "Coronavirus disease 2019 (COVID-19) Situation Report - 97," Geneva, 2020.

[4] CSSE, "Coronavirus COVID-19 Global Cases," Maryland, 2020.

[5] BNPB, "Situasi Virus COrona," Badan Nasional Penanggulangan Bencana, 2020. [Online]. Available: https://www.covid19.go.id/situasi-virus-corona/. [Accessed: 20-Mar2020].

[6] BNPB, "Surat Keputusan Kepala BNPB Nomor 9.A Tahun 2020 tentang Penetapan Status Keadaan Tertentu Darurat Bencana Wabah Penyakit akibat Virus Corona di Indonesia," Jakarta, 2020.

[7] WHO, "Country \& Technical Guidance - Coronavirus disease (COVID-19)," Coronavirus disease 2019, 2020.

[8] WHO, "Coronavirus disease (COVID-19) advice for the public," Coronavirus disease (COVID-19), 2020.

[9] Kemenkes RI, "Dokumen Resmi dan Protokol Penanganan COVID-19," Kesiapsiaagaan Menghadapi Infeksi COVID-19, 2020. .

[10] Dinas Kesehatan Provinsi Jawa Tengah, "Peta Sebaran Kasus COVID-19 di Jawa Tengah," Semarang, 2020.

[11] Dinas Kesehatan Kota Semarang, "Informasi Coronavirus (COVID-19) Semarang," Semarang, 2020.

[12] Mayor of Semarang, "Keputusan Walikota Nomor 443/417 Tahun 2020 Tentang Pemberlakuan Pelaksanaan Pembatasan Kegiatan Masyarakat Dalam Rangka Percepatan Penanganan Corona Virus Desease 2019 (COVID 19) Di Kota Semarang," Semarang, 2020.

[13] D. L. Heymann and N. Shindo, "COVID-19: What is Next for Public Health?," Lancet, vol. 395 , no. 10224 , pp. 542-545, 2020.

[14] S. Li, Z. Ye, Q. Wei, C. Du, and C. He, "The residents' mental health status and community' $\mathrm{s}$ role during COVID-19 epidemic: a community-based cross-sectional study in China," BMC Public Heal. (not Complet. peer Rev., pp. 1-16, 2020.

[15] R. R. Dangi and M. George, "A Review on Theories and Models of Disease Causation for COVID-19," 2020.

[16] N. I. Nii-trebi, "Emerging and Neglected Infectious Diseases : Insights, Advances, and Challenges," Biomed Res. Int., vol. 2017, pp. 1-15, 2017. 
[17] S. Notoatmodjo, Kesehatan Masyarakat Ilmu dan Seni. Jakarta: Rineka Cipta, 2007.

[18] S. Notoatmodjo, Konsep Perilaku Kesehatan. Promosi Kesehatan: Teori dan Aplikasi Edisi Revisi 2010. Jakarta: Rineka Cipta, 2010.

[19] WHO, "Key considerations for repatriation and quarantine of travelers in relation to the outbreak of novel coronavirus 2019-nCoV," Article, 2020.

[20] Kemenkes RI, Pedoman Pencegahan dan Pengendalian Coronavirus Disease (COVID19). Jakarta: Keme, 2020.

[21] H. Ardiyanti, "Komunikasi Media Yang Efektif Pada Pandemi Covid-19," Pus. Penelit. Badan Keahlian DPR RI, vol. 12, no. 7, p. 30, 2020.

[22] S. A. R. Al-Dubai, K. Ganasegeran, A. M. Rahman, M. A. Alshagga, and R. Saif-Ali, "Factors Affecting Dengue Fever Knowledge, Attitudes and Practices among selected Urban, Semi-urban and Rural Communities in Malaysia," Southeast Asian J. Trop. Med. Public Heal., vol. 44, no. 1, pp. 37-49, 2013.

[23] S. Notoatmodjo, Pendidikan dan Perilaku Kesehatan. Jakarta: Rineka Cipta, 2003.

[24] D. Montung, "Hubungan Antara Karakteristik Individu, Pengetahuan, Sikap Dengan Tindakan Masyarakat Dalam Pencegahan Demam Berdarah Dengue Di Wilayah Kerja Puskesmas Kolongan Minahasa Utara," Sam Ratulangi University, 2012.

[25] Lindawati, B. Miradwiyana, and Sumiati, "Faktor-Faktor Yang Mempengaruhi Perilaku Merokok SiswaSiswi SMP Di Daerah Jakarta Selatan Tahun 2011," J. Heal. Qual., vol. 2, no. 4, pp. 189-200, 2012.

[26] A. P. M. Gomes et al., "Relationship between patient's education level and knowledge on oral health preventive measures," Int. Dent. Med. J. Adv. Res., vol. 1, no. 1, pp. 1-7, 2015.

[27] E. Zimmerman and S. H. Woolf, "Understanding the Relationship Between Education and Health," NAM Perspect., vol. 4, no. 6, 2014.

[28] Social Science in Humanitarian Action, "Compliance with physical distancing measures for COVID-19 and implications for RCCE in Eastern and Southern Africa," 2020.

[29] N. M. Kavanagh, R. R. Goel, and A. S. Venkataramani, "Association of County-Level Socioeconomic and Political Characteristics with Engagement in Social Distancing for COVID-19," Peer-review, pp. 1-8, 2020.

[30] Ministry of Health, "Peraturan Menteri Kesehatan Republik Indonesia Nomor 9 Tahun 2020." Ministry of Health, Jakarta, pp. 1-28, 2020. 